\title{
Interventional radiology and endovascular surgery in the treatment of ectopic pregnancies
}

\author{
Radiologia intervencionista e cirurgia endovascular no tratamento das prenhezes ectópicas
}

\author{
Vinicius Adami Vayego Fornazari ${ }^{1}$, Denis Szejnfeld ${ }^{1}$, Julio Elito Júnior ${ }^{1}$, Suzan Menasce Goldman ${ }^{1}$
}

\begin{abstract}
The advent of interventional radiology enabled remarkable advances in diagnosis and treatment of several situations in obstetrics and gynecology. In the field of obstetrics, these advances include temporary occlusion of the iliac arteries to the management of placenta accreta and/or prior, arteriovenous fistulas after embolization of uterine curettage and management of ectopic uterine and extra-uterine pregnancies. The non-tubal ectopic pregnancy, either cervical, abdominal, ovarian or in a cesarean scar, often represents major therapeutic challenge, especially when exists a desire to maintain fertility. Despite the systemic methotrexate therapy and surgical resection of the ectopic gestational sac be the most used therapeutic options, the interventionist approach of non-tubal ectopic pregnancies, direct injection of methotrexate in the gestational sac and intra-arterial chemoembolization of uterine arteries constitute in the currently literature viable, safe, effective modalities with low morbidity, shorter hospital stay, and rapid clinical recovery. Because of little variety of materials used, and the increase in training of specialists in the area, the radiological intervention as a treatment option in ectopic pregnancies is financially viable and present considerable accessibility in the world and at most of Brazilian medical centers.
\end{abstract}

Keywords: Pregnancy, ectopic; Chemoembolization, therapeutic; Radiography, interventional; Uterine artery embolization; Methotrexate

\section{RESUMO}

0 advento da radiologia intervencionista tornou possível avanços notáveis no diagnóstico e no tratamento de diversas situações, na área de ginecologia e obstetrícia. No campo da obstetrícia, esses avanços incluem oclusão temporária das artérias hipogástricas para o manejo de placenta acreta e/ou prévia, embolização de fístulas arteriovenosas após curetagem uterina e manejo de prenhezes ectópicas uterinas e extrauterinas. A gravidez ectópica não tubária, seja cervical, abdominal, ovariana ou na cicatriz de cesárea, muitas vezes representa grande desafio terapêutico, principalmente quando há desejo de manutenção da fertilidade. As opções terapêuticas mais utilizadas para o tratamento de prenhez ectópica não tubária, são: terapia sistêmica com metotrexato e ressecção cirúrgica do saco gestacional ectópico; porém a abordagem intervencionista com injeção direta de metotrexato no saco gestacional ou quimiembolização intra-arterial das artérias uterinas, apresentam-se na literatura recente, como modalidades terapêuticas viáveis, seguras, eficazes, com baixa morbidade, menor tempo de internação e rápida recuperação clínica. Devido ao diminuto arsenal de materiais utilizados e à crescente formação de especialistas na área, a intervenção radiológica, como opção de tratamento nas prenhezes ectópicas, é financeiramente viável e apresenta acessibilidade considerável no mundo e na maioria do centros médicos brasileiros.

Descritores: Gravidez ectópica; Quimioembolização terapêutica; Radiologia Intervencionista; Embolização da artéria uterina; Metotrexato

\section{INTRODUCTION}

The advent of interventional radiology enabled striking advances in diagnosis and treatment of a variety of conditions, particularly in obstetrics and gynecology throughout minimally invasive percutaneous techniques, without general anesthesia, shorter period of hospitalization, low morbidity and preservation of the uterus..$^{(1,2)}$

In the field of obstetrics, notable advances include temporary hypogastric artery occlusion for management of placenta accrete, embolization arteriovenous fistulae followed by curettage and management of complicated intrauterine and extrauterine ectopic pregnancies. ${ }^{(1-3)}$ The incidence of ectopic pregnancy is $2 \%$, and most of implants occur in the fallopian tubes $(90 \%){ }^{(3)}$

Non-tubal ectopic pregnancy (uterine cornua, cervical, abdominal, ovarian or cesarean scar pregnancy) often poses a major management challenge, particularly when fertility preservation is desired. ${ }^{(3-5)}$ Treatment options include systemic therapy with methotrexate, surgical

\footnotetext{
Universidade Federal de São Paulo, São Paulo, SP, Brazil.

Corresponding author: Vinicius Adami Vayego Fornazari - Rua Napoleão de Barros, 800, Vila Clementino - Zip code: 04024-002 - São Paulo, SP, Brazil - Phone: (55 11) 5908-7900 - E-mail: vfornazari@yahoo.com.br Received on: June 24, 2014 - Accepted: Oct 7, 2014

DOI: 10.1590/\$1679-45082015MD3168
} 
resection of the ectopic gestational sac, and the recently minimally invasive interventional techniques: direct administration of methotrexate by ultrasound-guided injection into the gestational sac or endovascular uterine artery chemoembolization (EUAQ). ${ }^{(4,5)}$

Direct injection of methotrexate into the gestational sac is performed using an ultrasound needle-guidance technique. The direct treatment is indicated when ultrasound examination shows a live embryo. After antibiotic prophylaxis and disinfection of the vulvovaginal area, a 20G Chiba-type biopsy needle is coupled to the ultrasound transducer and advanced transvaginally, through the rectouterine pouch and into the amniotic sac, under color Doppler guidance so as to prevent vascular injury. As the amniotic sac is entered, gentle mechanical aspiration of the amniotic fluid is performed to prevent rupture and overdistension during later instillation of chemical agents (methotrexate $1 \mathrm{mg} / \mathrm{kg}$, or 1 to $3 \mathrm{~mL}$ of potassium chloride in a $2-\mathrm{mEq}$ solution, or hyperosmolar glucose $50 \%) .{ }^{(5)}$ The administration of methotrexate in locu ensures high local concentrations and lowers the risk of systemic toxicity. The other chemical agents (potassium chloride and hyperosmolar glucose) are preferred in cases of heterotopic pregnancy or in the presence of severe pulmonary disease, blood dyscrasia, or contraindications to methotrexate therapy. ${ }^{(5)}$

Ultrasound-guided injection into the gestational sac is a potentially effective treatment option for interstitial, cervical, and Cesarean scar pregnancies. ${ }^{(5)}$ However, due to larger amniotic sac volume and greater tissue vascularity, the risk of intraoperative and postoperative hemorrhage may be greater than in tubal pregnancies. ${ }^{(5)}$

Since the 1960s with the introduction of endovascular catheter technique by Charles Dotter, a constant technological development has also enabled the advent of high-performance microcatheters, which enable more distal (i.e., closer to the target site) selective arterial cannulation and, when combined with more compressible microspheres and in even smaller gauges, should enable more effective and selective arterial occlusion. Thus arose the endovascular interventional radiology technique known as intra-arterial chemoembolization, which combines selective, in locus delivery of high concentrations of chemotherapeutic agents - with minimal systemic effects - and the additional effects of embolization. $^{(1,5)}$

Intra-arterial chemoembolization was first described as a potential treatment for ectopic pregnancies in 2010 by Yang et al., who proposed it as an alternative of preventing the uterine scar ruptures and massive hemorrhages often caused by direct injection of chemotherapeutics into the gestational sac and adjacent endometrium. ${ }^{(6)}$
Takaeda et al. in 2010 also reported the use of dactinomycin instead of methotrexate, ${ }^{(7)}$ and $\mathrm{Wu}$ et al. proposed this technique as an option for management of gestational trophoblastic disease. ${ }^{(8)}$

Essentially, the technique consists of endovascular infusion of methotrexate into the uterine arteries followed by microsphere embolization, thus ensuring direct exposure of the embryo to high dose of methotrexate and, consequently, greater ischemia and trophoblastic degeneration, and reduction of side effects. ${ }^{(4,6)}$

The procedure can be performed under spinal anesthesia and conscious sedation with standard antibiotic prophylaxis. After asepsis of groin area, the right or left common femoral artery is cannulated via the Seldinger technique, introducer $5 \mathrm{~F}$, and the procedure continues such as in the uterine fibroid embolization, with catheterization of the left uterine artery and subsequently the right uterine artery, however, a 100mg dose of methotrexate is injected transarterially prior to embolization with occluding microparticles (PVA Boston Scientific e Cook Medical; Embosphere Biosphere medical; Bead Block - Terumo Medica; Embozene - Celonova Biosciences), always larger than $500 \mu$ to avoid paradoxical embolization to the ovary. ${ }^{(4)}$ Despite arterial occlusion, the risk of severe bleeding is non-negligible because of gradual restoration of the normal circulation within approximately 3 weeks. The dilation and curettage with suction or vacuum aspiration 6 to 8 hours after intra-arterial chemoembolization reduce the incidence of bleeding. ${ }^{(4,6,7-10)}$

To date, most cases reported on endovascular uterine artery chemoembolization were described by a Chinese group. Their study included 46 patients diagnosed with ectopic pregnancy in the cesarean scar and who were treated with the technique. According to their prospective and randomized trial, the ectopic mass disappears within approximately 33 days, serum human chorionic gonadotropin ( $\beta$-HCG) levels return to normal within 37 days, and the mean length of hospital stay was 10 days. ${ }^{(9)}$ There were few cases of severe complications (labial or vaginal necrosis, vesical fistula, endometrial atrophy, and premature ovarian failure) or treatment resistance that required conversion to cesarean delivery. ${ }^{(6-10)}$ It bears stressing that contraception is required for at least 3 months after the procedure. ${ }^{(4)}$ The same Chinese study exposed a technical success of $97.8 \%$ and concluded that endovascular uterine artery chemoembolization is a safe and effective method. ${ }^{(9)}$

To reduce the adverse effects to life and fertility, the uterine artery chemoembolization endovascular should follow the same principles of minimization of ionizing radiation established in uterine artery embolization for 
treatment of fibroids: collimators, decreased exposure time and fluoroscopy images acquired by subtraction and proper planning before proceeding with diagnostic methods without ionizing radiation. ${ }^{(5)}$

Despite the systemic therapy with methotrexate and surgical resection of the ectopic gestational sac constitute the most used therapeutic options for pregnancies ectopics, the interventional methods, especially the endovascular uterine artery chemoembolization, according to the articles we reviewed, are reported as a viable, safe and effective, with minimal morbidity, relatively brief hospitalization and rapid recovery..$^{(4,6-10)}$ Therefore, because interventional radiology treatment requires a small amount of materials to be conducted (one surgical arch, one introducer, two catheters, one microcatheter and low amount of occluding microparticles), this therapeutic modality for ectopic pregnancies is a financially viable method and relative available at several health services in Brazil and around the world.

\section{REFERENCES}

1. Messina ML, Deutsch F, Zlotnik E, Nasser F, Affonso BB, Melo NR, et al. Endovascular surgery in gynecology. Einstein (Sao Paulo). 2010;8(4):488-94.
2. Lippi UG. Interventional radiology to treat severe obstetric hemorrhages. Einstein (Sao Paulo). 2011;9(4):552-4.

3. Katz MD, Sugay SB, Walker DK, Palmer SL, Marx MV. Beyond hemostasis: spectrum of gynecologic and obstetric indications for transcatheter embolization. RadioGraphics. 2012;32(6):1713-31.

4. Elito Júnior J, Araujo Júnior E, Martins Santana EF, Szejnfeld D, Helfer TM, Nardozza LM, et al. Uterine artery embolization with methotrexate infusion as treatment for cesarean scar pregnancy. Case report. Med Ultrason. 2013; 15(3):240-3.

5. Thabet A, Kalva SP, Liu B, Mueller PR, Lee SI. Interventional radiology in pregnancy complications: indications, technique, and methods for minimizing radiation exposure. RadioGraphics. 2012;32(1):255-74.

6. Yang XY, Yu H, Li KM, Chu YX, Zheng A. Uterine artery embolisation combined with local methotrexate for treatment of caesarean scar pregnancy. BJOG. 2010;117(8):990-6

7. Takeda A, Koyama K, Imoto S, Mori M, Nakano T, Nakamura H. Diagnostic multimodal imaging and therapeutic transcatheter arterial chemoembolization for conservative management of hemorrhagic cesarean scar pregnancy. Eur $\mathrm{J}$ Obstet Gynecol Reprod Biol. 2010;152(2):152-6.

8. Wu X, Zhang X, Zhu J, Di W. Caesarean scar pregnancy: comparative efficacy and safety of treatment by uterine artery chemoembolization and systemic methotrexate injection. Eur J Obstet Gynecol Reprod Biol. 2012;161(1):75-9.

9. Shen L, Tan A, Zhu H, Guo C, Liu D, Huang W. Bilateral uterine artery chemoembolization with methotrexate for cesarean scar pregnancy. Am J Obstet Gynecol. 2012;207(5):386 e1-6.

10. Li C, Li C, Feng D, Jia C, Liu B, Zhan X. Transcatheter arterial chemoembolization versus systemic methotrexate for the management of cesarean scar pregnancy. Int J Gynaecol Obstet. 2011;113(3):178-82. 